\title{
NATURAL LAW: VOET'S CRITICISM OF DE GROOT
}

\section{HJ Erasmus*}

Keywords: Hugo de Groot; Jacobus Arminius; Franciscus Gomarus; Gisbertus Voetius; Johannes Voet; freedom of will; predestination; determinism; Remonstrants and Counter-Remonstrants; orthodox Calvinism; lapsarianism; Synod of Dordt; the law of nature

\section{Introduction}

Hugo de Groot (Grotius) (1583-1645), internationally known as the father of international law, is also celebrated for his seminal works on the law of nature and for his exposition of seventeenth century Dutch civil law in his Inleidinge tot de Hollandsche Rechts-geleerdheid, first published in 1631. Johannes Voet's principal work is his comprehensive Commentarius ad Pandectas, published in two volumes in 1698 and 1704. In the commentary, his explanations of Roman law are followed by that of modern law (the jus hodiernum). The latter are to a large extent based on his lectures, and among the sources quoted, De Groot's Inleidinge "occupies pride of place". 1

$1 \quad$ See Feenstra \&Waal 1975: 41.

* Former Judge of the High Court of South Africa; Research Associate, Department of Private Law, University of Stellenbosch.

$\dagger \quad$ We regret to announce that the author of this article, former Judge HJ Erasmus, passed away on 15 June 2016. An obituary of this much-valued contributor to our journal appears in this volume of Fundamina. 
Voet does not enjoy the international acclaim accorded to De Groot, and his general views on the nature of law and the law of nature, as expounded in the first part of the first title of his Commentary, has not received much attention in scholarly discourse. ${ }^{2}$ Yet he remains a foremost representative of Dutch legal scholarship of the seventeenth century.

In his exposition of the law of nature, Voet expresses criticism of De Groot's views as to the basis (foundation) of the law of nature. The criticism provides fascinating insight into the exposure of De Groot and Voet to the subtleties of the esoteric theological debates in Reformed (Calvinist) circles of seventeenth-century Holland. The purpose of this note is to highlight the theological background to the difference of opinion between two prominent seventeenth-century Dutch lawyers as to the foundations of natural law.

\section{Religious debates}

As the seventeenth century commenced the Netherlands faced a number of problems. ${ }^{3}$ Foremost in the early years was the debate between the Leiden professors Jacobus Arminius (1560-1609) and Franciscus Gomarus (1563-1641) about the freedom of will, predestination and determinism. ${ }^{4}$ The Reformed (Calvinist) orthodoxy of the early seventeenth century resolved the problem of reconciling God's omnipotence and omniscience with human free will by the adoption of a doctrine of rigid and absolute predestination as an eternal decree of God.

Arminius leant towards the Pelagian emphasis on the free will of man. $\mathrm{He}$ contended that God elected on the basis of his foreknowledge of the individual's decision whether or not to accept God's offer of salvation; that is, he advocated a conditional predestination in contrast to the absolute (and double) predestination of John Calvin (1509-1567) and Theodore Beza (1519-1605). Arminius was vehemently opposed by Gomarus who firmly supported the orthodox Calvinist view on predestination.

The debate created deep divisions in Dutch society. De Groot was a firm supporter of Arminius, as were other prominent personalities such as Oldenbarneveldt, Episcopius and Uytenbogaert. When Arminius died in 1609, De Groot helped his successor, Simon Episcopius, in drawing up the famous Remonstrantie, a document in which five points of divergence from orthodox Calvinism are set out. The principal divergence that needs to be highlighted within the present context is the advocating of the conditional predestination of Arminius rather than the absolute (and double)

2 The only comprehensive evaluation of Voet's views of which I am aware is Domanski 2013: 251265.

3 For a brief but full account, see Price 1994: 109-205.

4 See Gottshchalk-Stuckrath 2010: 104-121. 
predestination of Calvin and Beza. The supporters of Gomarus countered with a "counter-Remonstrant" in which orthodox Calvinism was affirmed.

The Dutch Reformed Church (Nederlands Hervormde Kerk, previous Nederduits Gereformeerde Kerk) as established state church since 1579, had embraced particularly the Calvinist creed and it was inevitable that any attack upon its doctrine and authority would carry political overtones. The religious controversy aggravated the dispute between the province of Holland and the orthodox Calvinist majority of the States General under the leadership of Prince Maurits. The tolerant attitude of the Arminians elicited accusations of treason - Uytenbogaert was accused of having become a papist and that he and Arminius were pensioners of Catholic Spain. De Groot was looked upon as a crypto-catholic, and his plea for moderation in his Pietas Ordinum Hollandiae ac West-Frisiae Vindicata $(1613)^{5}$ had little impact.

Prince Maurits, with the support of the Counter-Remonstrants, resolved the issues by convening the Synod of Dordt in 1618. The Synod has, perhaps somewhat cynically, been described as an ecclesiastical smokescreen for the resolution of a political power struggle ("een kerkelijk rookgordijn waarachter een politieke machtstrijd werd beslecht"). ${ }^{6}$

At the Synod, the Counter-Remonstrants outnumbered the Remonstrants. Arminianism was rejected and Gomarus (who by then was professor in Groningen) vindicated. In addition, the orthodox view of predestination was confirmed. Remonstrant church services were banned and Remonstrant preachers (including Episcopius) were deposed. In the political outflow, Oldenbarneveldt was condemned to death and executed; Uytenbogaert was forced into exile; and De Groot was sentenced to life imprisonment and incarcerated in Loevenstein castle from where he made his famous escape after two years.

It was during this period that the esoteric supra-infralapsarian debate became part of the theological discourse in orthodox Calvinism. ${ }^{7}$ In Calvinist theology, lapsarianism concerns the logical order of God's eternal decrees of salvation: Did God's decree to save certain people come before (supra, ante) or after (infra, post or $s u b$ ) the decree to permit the fall (lapsus) of mankind into sin? According to supralapsarians, the double predestination of election and reprobation occurred prior to God's decree that encapsulates mankind's fall (lapsus) into sin. Infralapsarians insisted that the decree of predestination follows on the decree of creation and the fall into sin. The Canons of Dordt softened the doctrine of predestination in the direction of infralapsarianism though supralapsarianism was not explicitly rejected. Gomarus continued to hold strong supralapsarian views.

5 The full title is Ordinum Hollandiae ac Westfrisiae pietas ab improbissimis multorum calumnis, praesertim vero a nupera Sibrandi Lubberti epistola quam ad reverendissimum archiepiscopum Cantuariensem scripsit, vindicata per Hugonem Grotium (Lugdunum Batavorum, 1613).

6 Panhuysen 2015: 182.

7 See Durand 2007: 175. 
The youngest delegate to attend the Synod of Dordt was Gisbertus Voetius, at the time preacher at Vlijmen. He was a strong supporter of Gomarus and they remained firm supralapsarians.

\section{Gisbertus (Gijsbert) Voetius (1589-1676)}

The paths of Gisbertus Voetius and De Groot crossed when Voetius was still a young preacher and De Groot was advocaat-fiscaal of Holland, Zeeland and Friesland. In Heusden, where Voetius was born, the Arminian party had for years tried to prevent his nomination as minister. De Groot more than once intervened in the conflict with Voetius' Remonstrant colleague Johannes de Greeff. Voetius had his "revenge" many years later, at a provincial synod in Leiden in 1620, when De Greeff was banished and ended up in Germany. ${ }^{8}$

Gisbertius Voetius ${ }^{9}$ became Professor of Theology, Hebrew and Oriental Languages at Utrecht in 1634. He held the position till his death in 1676 . He was a formidable, often controversial figure. He engaged in theological debate with Catholics, Arminians, Jansenites and Socinians. Inspired by English Puritanism, he became a leading figure in the so-called Nadere Reformatie (Dutch Second Reformation) which called for a Christian purification of society through the private and public practice of piety. In 1640 he became involved in a drawn-out dispute with Descartes, which was to become known as the Querelle d'Utrecht. Voetius also opposed the Covenant Theology of the Leiden theologian Johannes Cocceius (16031669). The Voetian-Cocceian controversy persisted in the Reformed Church until long after the death of the initial antagonists. ${ }^{10}$ At the time of his death, Voetius was involved in a controversy with one Cephas Pistophilus. This was the pseudonymn of Petrus Allinga who was born in Enkhuizen, studied in Utrecht, and thereafter became preacher in Wijderen in Noord-Holland. He has been described as "a strong supporter of Cartesian Coccejanism" ("een hevig voorstander van het Cartesiaansche Coccejanisme"). ${ }^{11}$

Voetius' son Paulus was in 1635 appointed Professor of Metaphysics at Utrecht, and Professor of Roman law in 1654. Paulus' wife, Elizabeth van Winssen, died when her son Johannes was still a child. Paulus raised his son as a single parent, remarrying when Johannes was about sixteen. This may account for the life-long

8 "A Short Biography of Gisbertus Voetius (1589-1676)" (accessed 12 Oct 2015) available at https:/witsius.wordpress.com/2011/09/17/a-short-biography-of-gisbertus-voetius -158. With the material at my disposal, I was unable to follow up on the allegation by Howard Hotson that this was taken over word for word, without acknowledgment, from Henri Krop's article in the Dictionary of Seventeenth- and Eighteenth-Century Dutch Philosophers (Bristol, 2003).

9 The standard biography is that by Duker 1897-1915.

10 See the collection of essays in Van Asselt et al 1994.

11 Molhuysen \& Blok 1918: 37. His role in the Voetian-Cocceijan debate is considered by Van der Wall 1994: 131-145. 
close relationship between grandfather and grandson. ${ }^{12}$ Voetius dedicated the second part of his Politica Ecclesiastica (1669) to his grandson.

\section{$4 \quad$ Hugo de Groot (1583-1645)}

Like Johannes Voet, De Groot was a deeply religious man and a devout Christian. ${ }^{13} \mathrm{He}$ had a large body of theological works to his name which were collected and published after his death. ${ }^{14}$ De Groot's spiritual and intellectual roots are in the Renaissance and Christian Humanism of More, Colet, Desiderius Erasmus, Arminius and the Spanish scholastics. ${ }^{15}$ GHM Posthumus Meyjes ${ }^{16}$ says that De Groot was "primarily a Christian Humanist scholar whose desire was to uphold and continue the religious programme as interpreted in the $16^{\text {th }}$ century by Erasmus and others, in defiance of the bitter reality of a Christian world split and hardened by confessional differences".

De Groot rejected as unreasonable and illogical the determinism of orthodox Calvinism and defended the doctrine and ideal of freedom of the will. ${ }^{17} \mathrm{AH}$ Haentjens says that "[d]e erkenning van de wilsvryheid was voor hem een onontbeerlijk en zeer belangrijk onderdeel van die waarheid van den Christelijken godsdienst". ${ }^{18}$ The doctrine of the freedom of will finds powerful expression in De Groot's theological works such as his De Veritate Religionis Christianae. ${ }^{19}$

De Groot's understanding of natural law must be seen against this background. It has been said that his understanding of natural law cannot be divorced from his theology, and that we cannot understand his ideas on natural law without recognising their theological nature. ${ }^{20}$

De Groot's natural law doctrine makes a first brief appearance in the second chapter of his De Jure Praedae, written in 1604, but published only in $1868 .{ }^{21}$ It is thereafter set out in detail in the Prolegomena and first and second Books of his De

12 See De Wet 1948: 51; Duker 1897-1915 Part 9 states that “(e)en lichtpunt was werderom in Voetius' familie de zeldzaam-gunstige aanleg en ontwikkeling van Johannes, oudste zoon van Paul uit diens eersten echt".

13 Pont 1945: 190 says that De Groot was a "diep religieuse mens".

14 Hugonis Grotii Opera Omnia theologica: in tres tomos divisa ante quidem per partes, nunc autem conjunctim et accuratius edita: quid porro huic editioni prae ceteris accesserit, praefatio ad lectorem docebit (Amsterdam, 1679).

15 See Haentjens 1946: passim; Van der Wall 1994: 51-58; and Decock 2013: passim.

16 Van der Wall 1994: 52.

17 See Vetterli \& Bryner 1993: 370-402.

18 Haentjens 1946: 76-77.

19 It was first published in 1622 in Dutch under the title Bewys van den waren godsdient, in ses boeken gestelt by Hugo de Groot, and in 1627 in Latin under the title Sensus librorum sex, quos pro veritate religionis Christianae Batavice scripsit Hugo Grotius (Lugduni Batavorum, 1627). See Knight 1962: 168ff.

20 Vetterli \& Bryner 1993: 371-372.

21 Hugonis Grotii De jure praedae commentarius. Ex auctoris codice descripsit et vulgavit HG Hamaker (Hagae Comitum, 1868). 
Jure Belli ac Pacis (1625) and ultimately finds mention in summarised form in the Inleidinge (1631). His theories have been subjected to detailed scholarly analysis and searching criticism. It is not my intention to indulge in yet another such analysis. It is sufficient for present purposes to trace, in summary form, his thoughts on the source of law, and of the law of nature.

In the Prolegomena ${ }^{22}$ to the De Jure Belli ac Pacis De Groot says the following about the source (fons) of law: ${ }^{23}$

This maintenance of the social order, which we have roughly sketched, and which is constant with human intelligence, is the source of law properly so called. ${ }^{24}$

In a later paragraph ${ }^{25}$ of the Prolegomena De Groot says that there is also another source of law besides the source in nature:

Another source of law besides the source in nature, is the free will of God to which beyond all cavil our reason tells us that we must render obedience. ${ }^{26}$

These two passages encapsulate in summary form the essence of De Groot's thinking on the source and nature of law. Human reason is for him the basis of the laws and institutions of society. But law also has a divine base, the free will of God, which it is for man to discover and apply. Reason is accordingly the means by which man gains knowledge of law in nature and of the will of God.

Building on this foundation, De Groot defines natural law as follows: ${ }^{26}$

The law of nature is a dictate of right reason, which points out that an act according as it is or is not in conformity with rational nature, has in it a quality of moral baseness or moral necessity; and that, in consequence, such an act is either forbidden or enjoined by the author of nature, God. ${ }^{28}$

The idea that the source of natural law is to be found in the rational and social nature of man is re-stated in the passage singled out by Voet in his criticism of De Groot: ${ }^{29}$

(1) In two ways men are wont to prove that something is according to the law of nature, from that which is antecedent and from that which is consequent. Of the two lines of proof the

22 Paragraph 8.

23 The translations cited of passages from the De Jure Belli ac Pacis are by Kelsey 1925.

24 "Haec vero quam rudi modo iam expressimus societatis custodia, humano intellectui conveniens, fons est ejus juris quod proprio tali nomine appellatur."

25 Paragraph 12.

26 "Et haec iam alia juris origo est praeter illam naturalem, veniens scilicet ex libera Dei voluntate, cui nos subjici debere, intellectus ipse noster nobis irrefragabiliter dictat."

27 De Jure Belli ac Pacis 1110.

28 "Ius naturale est dictatum rectae rationis indicans actui alicui, ex ejus convenienta aut disconvenientia cum ipsa natura rationali, inesse moralem turpitudinem aut necessitatem moralem, ac consequenter ab auctore naturae Deo talem actum aut vetari aut praecipi."

29 De Jure Belli ac Pacis 1121. 


\section{HJ ERASMUS}

former is more subtle, the latter more familiar. Proof a priore consists in demonstrating the necessary agreement or disagreement of anything with a rational and social nature; proof a posteriori, in concluding, if not with absolute assurance, at least with every probability, that that is according to the law of nature which is believed to be such among all nations, or among all those that are more advanced in civilization. For an effect that is universal demands a universal cause; and the cause of such an opinion can hardly be anything else than the feeling which is called the common sense of mankind. ${ }^{30}$

Finally, De Groot's concept of natural law is summarised in his Inleidinge ${ }^{31}$ in a form which embraces the very essence of his thinking: ${ }^{32}$

(4) Law is either natural or positive.

(5) The natural law of man is the dictate of reason pointing out what things are in their very nature honourable or dishonourable, with an obligation to observe the same imposed by God. $^{33}$

It is to be expected that the idea that first principles of natural law have their origin in the social consciousness and the dictates of reason of man would be anathema to orthodox Calvinism with its firm belief in divine determinism and predestination.

\section{Johannes Voet (1647-1713)}

Johannes Voet was appointed as Professor Ordinarius Pandectarum at Utrecht in 1673 where his grandfather had been Professor of Theology since 1634. After the death of his grandfather, he accepted an invitation to Leiden where he remained till his death on 9 September 1713.

His personal life was that of a devout Christian: he served as a member of the church council of the Reformed Church in Utrecht.

In his professional life he remained in essence a lawyer whose main achievement was the exposition of the current Dutch civil law in the light of the Pandects of Roman law. His Christian convictions, however, come to the fore in his discussion of the fundamental principles of law and justice, of equity and justice and of natural

30 "Esse autem aliquid juris naturalis probari solet tum ab eo quod prius est, tum ab eo quod posterius, quarum probandi rationum illa subtilior est, haec popularior. A priori, si ostentatur rei alicujus convenientia aut disconventia necessaria cum natura rationali ac sociali: a posteriori vero, si non certissima fide, certe probabiliter admodum, juris naturalis colligitus id, quod apud omnes gentes, aut moriatores omnes tale esse creditur. Nam universalis effectus universalem requirit causam: talis autem existimationis causa vix ulla videtur esse posse praeter sensum ipsum, communis qui dicitur."

$31 \quad 12$ (4) and (5).

32 The translation is that of Maasdorp 1903.

33 "(4) Want alle Wet is aangeboren ofte gegeven. (5) Aangeboren wet in den mensche is het oordeel des verstands, te kenne ghevende wat zaken uit haer eigen aerd zijn eerlick ofte oneerlick, met verbintenisse van Gods wegen om’t zelve te volgen." 
law. ${ }^{34}$ Gisbertius Voetius' Politica Ecclesiastica is often mentioned in the early part of the Commentarius, and in his title on high treason ${ }^{35}$ the grandson refers to his grandfather's Disputatio on atheism.

The devotion of Johannes to his grandfather, and what he stood for, is apparent from the defence of his grandfather who, at the time of his death in 1676, had been involved in a theological disputation with Cephas Pistophilus (Petrus Allinga) who, as has been pointed out above, was "a strong supporter of Cartesian Coccejanism". Johannes' defence appeared in print in 1676:

Iohannis Voet responsio ad libellum personati cujusdam Cephae Pistophili, titulo Sententia Theologorum veterum et recentiorum, ... De amore in fide, contra inamadversiones Gisberti Voetii (Hagae Comitum, 1676).

Cephas Pistophilus responded by an attack on Johannes Voet:

Cephae Pistophili Epistulae duae responsoriae ad consultissimum et doctissimum D. Johannem Voet, Juris in Academia Ultrajectina Professorem, pro Defensio Sententiae Theologorum Veterum et Recentiorum de Amore in Fide (Lugdunum Batavorum, 1677).

Voet also refers to the matter in the Praefatio of his Compendium juris juxta seriem Pandectorum (1683) where he defends himself against his calumniator. In the preface, Voet refers to his latest letter to a friend typis expressa. The letter to which Voet refers ${ }^{36}$ was published in 1679 under the title Epistola ad amicum de Petri Allingae praefatione Erotematibus praemissa..$^{37}$

Within the stark divisions in Reformed circles in seventeenth-century Holland, Johannes Voet and De Groot belonged to opposing camps. The spiritual roots of Johannes Voet are in the orthodox Calvinism propounded by his grandfather. Those of De Groot are in the Christian Humanism of Desiderius Erasmus and others. It was inevitable that these differences would be reflected in their concept of the fundamental principles of law and justice, and of natural law. What is more, in their discourse the supra-infralapsarian discourse raises its head in a subtle way.

Voet has a fair amount of criticism about the matter: It will be convenient, at the outset, to have regard in some detail to his opening statement in the first title of the first book of the Commentarius ad Pandectas in which he states as follows: ${ }^{38}$

34 See Domanski 2013: passim.

354814.

36 Roberts 1933: 15 refers to Cephas Pistophilus as "unknown" to him and was unable to trace the letter.

37 Epistola ad amicum de Petri Allingae praefatione Erotematibis praemissa Ultrajecti, apud Franciscum Halma 1679 (as part of Melchior Leydecker Vis Veritatis, sive disquisitionum ad nonnullas controversias quae hodie in Belgio potissimum moventur de Oeconomia Foedorum Dei, Libri quinque (Utrecht 1679). See Feenstra \& Waal 1975: 39 n 158.

38 The translations of passages from the Commentarius ad Pandectas are all from Gane (19551959). 


\section{HJ ERASMUS}

Whenever our fancy leads us to scan with close attention the origins, the growth as well and the prolonged continuation of right up to the present day of mankind, we shall find that at no time and in no place has it found itself without law of right and honour. This was not so even in those quarters or ages in which savage mortals knew nothing whatever of the way of a life with culture, but in which herbs and acorns were their food, the forests their homes, and their woodland beds spread by their hill-wives.

It is quite true that the use of untainted reason, precise in everything and unacquainted with deceit, perished along with the original uprightness of morals owing to the fall of our firstformed parents (per lapsum protoplastarum).

Yet strength of mind and sense of virtue were not so utterly extinguished in mankind that no few sparks remained of the principles of justice and honour, like rubble from some fine mansion or planks taken from a wrecked ship. Thus certain rules of justice and equity remained divinely engraved on men's hearts and inborn, dictating to each one what was lawful or unlawful, what things to do and what to avoid. These rules no man, if he debates it with himself and reflects privately upon them in quietness of mind, eradicate without an inward conflict. Not only does Holy Writ invoke them, but even the best and most learned of heathen recognize them ... ${ }^{39}$

The use by Voet of the term per lapsum protoplastarum is revealing: lapsus is the term used in theological discourse in Latin to denote the Fall of Man as described in Genesis, the first Book of the Christian Bible. ${ }^{40}$ Protoplastus (derived from the Greek $\pi \rho \omega \tau 0 \pi \lambda \alpha \sigma \tau$ ó $\zeta)$ is used to denote the first formed man, Adam, and in the plural, the first of mankind. ${ }^{41}$ What Voet is in essence saying is that the principles of law were in existence before the fall of mankind into sin, that after the fall there remained ingrained into the hearts of men some remnants (scintillae) of the knowledge of right and wrong, but that these were ascertainable not by man's own efforts, but in Holy Scripture (sacrae literae) and in the teachings of the best and most learned men.

39 "Quoties cum generis humani primordiis eiusdem quoque incrementa, et in hunc usque diem productam durationem, attenta contemplatione libet intueri; nullo umquam loco, nullo tempore, illud sine recti honestique legibus substitisse deprehendemus; ac ne illis quidem aut regionibus, aut seculis, quibus seri mortales omnem ignorabant vitae cultioris usum, quibus herbae ac glandes victus iis, nemora domus, ac thorum sylvestrem montana frondibus sternebat uxor. Quamvis etiam per lapsum protoplastarum cum primaeva morum integritate perierit quoque in exactus in omnibus et fallere nescius incorruptae rationis usus: non tamen ita in universum in hominibus extinctus fuit aut mentis vigor, aut virtutis sensus, quin scintillae quaedam principiorum justi et honesti superfuerint, quasi rudera agregiae domu, aut tabulae ex naufragio subductae; atque adeo cordibus insculptae divinitus et innatae remanserit nonnullae justitiae et aequitatis regulae, quid licitum illicitumve, quae agenda, qaue fugienda sint, cuique dictantes: quas et quisque semetipsum sedato excutiens animo, secumque cogitans, non potest non Marte proprio eruere: non sacris tantum literis illud indigitantibus, sed et agnoscentibus gentilium optimis, atque doctissimis ..."

40 See Latham (ed) 1965: sv "lapsus".

41 See Latham (ed) 1965: sv "proto - protoplastus". The forms "protoplaustus", "protoplasta" and "protoplausta" also occur. The term is used by the early Christian (patristic) writer Tertullianus in his De Exortatione Castitatis 2 fin and Adversus Judaeos 13. 
Underlying Voet's concept of law and of the basis of natural law is the supralapsarian thinking of orthodox Calvinism. In Commentarius 1114 he states:

It is enough to say that God, the creator of nature, is also the founder of natural law ... ${ }^{42}$

\section{In Commentarius 1115 he adds that}

natural law is more ancient than any human society; and hence society, being later than that law, cannot be conceived as the foundation of that law, which is prior in time. ${ }^{43}$

This is the background of Voet's criticism of De Groot as enunciated in Commentarius 1115 . He asks the question as to the primum principium (first principle) of natural law, and observes that there are many diverse answers to the old question of the highest good (summum bonum). He proceeds as follows:

As to what is the groundwork of this natural law, what is the foundation and first principle from which it can be proved a priori (as they say $)^{44}$ and as it were drawn out of the holy shrine of justice itself, and what is the province of natural law, there has been no fewer disagreements on those points than in the many discordant opinions which divided philosophers of old on the question of the highest good (summum bonum).

Some thought it right to place the foundation in a concordance or discordance with natural and social reason before it had been sullied by the fall of man (Grotius De Jure Belli ac Pacis 11 12). But what, pray, is that but to beg the question? The very question is whether this thing or that is in concordance with uncorrupted nature or right reason; and it follows that the answer must be derived from some other foundation. Others seek the main principle of all natural law in the social character of man (Pufendorf De Jure Naturae et Gentium, in the preface). ${ }^{45}$ But not rightly, in my opinion; for natural law embraces in its scope not only duties to other men living in the same society, but also towards God and towards one's own self, even when sundered from all relation to human society. ${ }^{46}$

\section{Voet states his final conclusion as follows (Commentarius 111 15):}

This being so, nothing strikes one more clearly on deep examination of the whole matter than that the source and wellhead of the whole of natural law, from which every principle of

42 "Sufficit, Deum, auctorem naturae, juris quoque naturalis conditorem esse ..."

43 "Jus naturae omni societate humana antiquius est; unde societas, eo jure posterior, concipi non potest juris illius."

44 This is an allusion to De Groot De Jure Belli ac Pacis 112 which is quoted above.

45 In his De Jure Naturae et Gentium (1672) Samuel Pufendorf took up the theories of De Groot and sought to complete them by the doctrines of Hobbes and his own ideas on the jus gentium.

46 "Sunt enim, quibus visum fuit ejus fundamentum ponere in conventia et disconventia cum natura rationali ac sociali, non per lapsum depravata. Grotius De Jure Belli ac Pacis 1.12. Sed quid, obsecro, est principium petere, si non hoc? Cum id ipsum in quaestione sit, an hoc aut illud sit conveniens incorruptae naturae seu rectae rationi: ut proinde ex alio id feurit fundamento deducendum. Alii in hominis socialitate primum juris totius naturalis quaerunt principium. Puffendorf De Jure Naturae et Gentium in praefat. Sed, ut opinor, minus recte: cum jus naturale ambitu suo non modo complectatur officia erga hominos alios, in eadem viventes societate; sed et erga Deum, et semet ipsum, etiam ab omni societatis humanse relatione remotum." 
justice will have to be derived like streams from a source, or boughs from a tree, is nothing but the law of God the Creator (ex qua, uti ex fonte rivali, ex radice rami, derivanda erit omnis justitiae ratio, quam jus Dei creatoris), mighty as $\mathrm{He}$ is, and yet at the same time kind and most generous to all His creatures. Why, God thrice Great and High (Deus ter Optimus Maximus $)^{47}$ brought to being man himself and all things else for his benefit. Man seeing this with right reason and own judgment, and acknowledging the high benevolence, wisdom and power of the Creator, cannot but be conscious and convinced of the very close obligation arising from the very blessing of his creation. ${ }^{48}$

In the ultimate result, the difference between De Groot and Voet is to be found in the way in which they conceive the role of mankind's freedom of will. For De Groot, the law of nature finds its foundation and substance in the dictates of right reason, and right reason is firmly within the sphere of mankind's freedom of will. Voet finds the origin of the law of nature in an eternal decree of God, and mankind's role is confined to acknowledgment of the wisdom and power of God, and consciousness of the obligation arising from this blessing of God's creation. ${ }^{49}$

\section{Conclusion}

Voet' criticism of De Groot's concept of the first principles underlying the law of nature has left little or no traces in subsequent debates or learned discourse among the writers on the Roman-Dutch law. Both Van der Keessel and Van der Linden in their respective commentaries on De Groot's Inleidinge followed De Groot's views without making any reference to Voet.

By the time Voet penned his criticism of De Groot, the vehemence which had characterised the theological debate in the early part of the seventeenth century had abated. Moreover, the lawyers were not interested in this kind of debate, and the

47 Underlying this is the doctrine of the Holy Trinity which is central to much of Christianity, including orthodox Calvinism.

48 "Quae cum ita sint, poenitus cuncta scrutanti non alius evidentius occurit juris naturalis universi fundamentum ac scaturgio, ex qua, uti ex fonte rivali, ex radice rami, derivanda erit omnis justitiae ratio, quam jus Dei creatori, potentis quidem, sed et pariter benigni ac summe benefici in suas creaturas. Produxit nempe Deus ter Optimus Maximus ipsum hominem, et omnia reliqua in usum ejus. Quod ratione recta ac judicio suo homo percipiens, et benevolentiam, sapientiam, potentiamque creatoris agnoscens maximam, non potest non sibi conscius ac convictus esse natae ex ipso creationis beneficio obligationes illius arctissimae ..."

49 It is beyond the scope of this note to explore the extent to which the divergent views of both De Groot and Voet find their roots in medieval scholasticism. Durand 2007: 186 refers to "[ $t$ ] he heavy scholasticism of Reformed Orthodoxy" which "became dominant in the Reformed Churches of the Netherlands". Knight 1925: 84 points out that the De Jure Praedae, which "may have been almost a first draft" of the De Jure Belli ac Pacis, "is in form, and very much in substance, a work most carefully cast in the scholastic mode". De Groot's indebtedness to the Spanish scholastics is traced in detail by Decock 2013 who concludes (at 643): "If anyone, Hugo Grotius appears to be the ultimate bridge-figure between the moral theologians and the 'modern' natural lawyers. A superficial indication of Grotius' indebtedness to the late medieval ius commune and the Spanish scholastics is the great number of references to these sources in the De iure belli ac pacis." 
churchmen were finding other points of debate in which they could vent the spleen of their odium theologicum.

\section{ABSTRACT}

Hugo de Groot (1583-1645) is internationally known as the father of international law and also celebrated for his seminal work on the law of nature. The principal work of Johannes Voet (1647-1713) is his Commentarius ad Pandectas in which he expounds the modern law (the jus hodiernum) in the light of the Pandects of Roman law. In the first title of his Commentary, Voet briefly sets out his views on the foundations of natural law. He rejects the views of De Groot on this score as unacceptable. The purpose of this note is to trace the exposure of De Groot and Voet to the subtleties of the esoteric theological debates in Reformed (Calvinist) circles in seventeenth century Holland, and to highlight the theological background to their differing views on the source of the law of nature.

\section{Bibliography}

Decock, Wim (2013) Theologians and Contract Law. The Moral Transformation of the Ius Commune (ca 1500-1650) (Leiden/Boston)

De Wet, JC (1948) “Jan Voet” THRHR 11: 50-57

Domanski, Andrew (2013) "Fundamental principles of law and justice in the opening title of Johannes Voet's Commentarius ad Pandectas" Fundamina 19(2): 251-265

Duker, AC (1897-1915) Gisbertus Voetius 4 Parts (Leiden)

Durand, Jaap (2007) The Many Faces of God. Highways and Byways on the Route towards an Orthodox Image of God in the History of Christianity from the First to the Seventeenth Century (Stellenbosch)

Feenstra, R \& Waal, CLD (1975) Seventeenth-Century Leyden Law Professors and their Influence on the Development of the Civil Law. A Study of Bronchorst, Vinnius and Voet (Amsterdam/ Oxford)

Gane, Percival (1955-1958) The Selective Voet: Being the Commentary on the Pandects (Paris edition of 1829) by Johannes Voet. And the Supplement to that Work by Johannes van der Linden, Translated with Explanatory Notes and Notes of all South African Reported Cases (Durban)

Gottschalk-Stuckrath, Linda (2010) “Arminius and Gomarus in Leiden: The predestination and free-will controversy in the Netherlands" in Marinello, TJ \& Drake Williams III, HH (eds) My Brother's Keeper. Essays in Honor of Ellis R Brotzman (Eugene): 104-121

Haentjens, AH (1946) Hugo de Groot als Godsdienstig Denker (Amsterdam-published by the Commissie tot die Zaken der Remonstransche Broederschap at the time of the commemoration of the death of De Groot in 1645)

Kelsey, Francis W (1925) Hugonis Grotii De Jure Belli ac Pacis trl by Kelsey, FW in collaboration with Boak, Arthur ER (Oxford) 


\section{HJ ERASMUS}

Knight, WSM (1962) The Life and Works of Hugo Grotius (New York)

Latham, RE (ed) (1965) Revised Medieval Latin Word-List (Oxford)

Maasdorp, AFS (1903) The Introduction to Dutch Jurisprudence of Hugo Grotius, with an Appendix Containing Selections from the Notes of William Schorer tr by Maasdorp, AFS (Cape Town)

Molhuysen, PC \& Blok, PJ (eds) (1918) Nieuw Nederlandsch Biografisch Woordenboek Part 4 (Leiden)

Panhuysen, Luc (2015) “De Sinode van Dordrecht (1618-1619)” Historisch Nieuwsblad available at http://www. Historischnieuwsblad.nl/nl/artikel/25933/de-sinode-van-dordrecht-1618-

Pont, A (1945) "Die 'Inleidinge tot de Hollansche Rechts-geleertheyd' van Hugo de Groot" THRHR 9: 182-201

Postumus Meyjes, GHM (1983) "Grotius as Theologian" in Hugo Grotius. A Great European 1583-1645 (Delft): 51-58

Price, JL (1994) Holland and the Dutch Republic in the Seventeenth Century. The Politics of Particularism (Oxford)

Roberts, AA (1933) A Guide to Voet (Pretoria)

Van Asselt, WJ et al (eds) (1994) Een Richtingenstrijd in the Gereformeerde Kerk. Voetianen en Coccejanen 1650-1750 (Zoetermeer)

Van der Wall, EGE (1994) "De coccejaanse theoloog Petrus Allinga en het cartesianisme" in Een Richtingenstrijd in the Gereformeerde Kerk. Voetianen en Coccejanen 1650-1750 (ed) WJ van Asselt et al (Zoetermeer): 131-145

Vetterli, R \& Bryner, G (1993) "Hugo Grotius and natural law: A reinterpretation" Political Science Rev 22: 370-402

\section{Works of De Groot referred to:}

Inleidinge tot de Hollandsche Rechts-Geleerdheid (met de te Lund teruggevonden verbeteringen, aanvullingen en opmerkingen van den schrijver en met verwijzingen naar zijn andere geschriften uitgegeven en van aantekeningen voorzien) door Dovring, F, Fischer, HFWD \& Meijers, EM 2nd ed (Leiden, 1965)

Ordinum Hollandiae ac Westfrisiae pietas ab improbissimis multorum calumnis, praesertim vero a nupera Sibrandi Lubberti epistola quam ad reverendissimum archiepiscopum Cantuariensem scripsit, vindicata per Hugonem Grotium (Lugdunum Batavorum, 1613)

Hugonis Grotii Opera Omnia theologica: in tres tomos divisa ante quidem per partes, nunc autem conjunctim et accuratius edita: quid porro huic editioni prae ceteris accesserit, praefatio ad lectorem docebit (Amstelodami, 1679)

Sensus librorum sex, quos pro veritate religionis Christianae Batavice scripsit Hugo Grotius (Lugduni Batavorum, 1627)

Hugonis Grotii De Jure Praedae Commentarius. Ex auctoris codice descripsit et vulgavit HG Hamaker (Hagae Comitum, 1868)

Hugonis Grotii De Iure Belli ac Pacis Libri Tres, in quibus ius naturae et gentium item iuris publici praecipua explicantur (Parisiis, 1625) 